\title{
Functional anatomy and intestinal morphometry of bullfrog tadpoles subjected to a dietary regime with commercial feeds
}

\author{
Anatomia funcional e morfometria do intestino de girinos de rã-touro \\ submetidos a regime alimentar com rações comerciais
}

\author{
José Teixeira de Seixas Filho ${ }^{*}$, Silvia Conceição Reis Pereira Mello ${ }^{1}$, Fabiane Toste Cardoso ${ }^{1}$, \\ Rodrigo Otavio Lopes de Souza'
}

${ }^{1}$ Centro Universitário Augusto Motta/UNISUAM, Rio de Janeiro, RJ, Brasil

*Corresponding author: seixasfilho@yahoo.com.br

Received in January 9, 2016 and approved June 27, 2016

\begin{abstract}
One of the main hindrances to frog farming is the lack of knowledge of the nutritional requirements of tadpoles that allow nutritionists to formulate the ideal diet for this phase, reducing operational costs and providing homogeneity to the shoal. This study aimed at evaluating the anatomy of the digestive tract and morphometry of the midgut and hindgut of bullfrog (Lithobates catesbeianus) tadpoles to provide subsidies for nutritionists to make adjustments in the balancing of suitable diets for this species. The population of tadpoles that received the dietary regimen named DR3, which consisted of a fortnight increase of the dietary protein levels (from 32 to $45 \%$ of CP) for 60 days, showed the best results regarding weight gain, survival rate, and homogeneity in the passage of the larval stages as compared with the other dietary regimens tested. Additionally, the morphometry of the intestines of the animals subjected to DR3 showed a greater length $(419.2 \mathrm{~mm})$ and higher caliber of the midgut portion where most of the nutrient absorption takes place. It can thus be inferred that this fact is related to the height of the absorptive intestinal folds resulting from the supply of a diet with better quality, confirmed by the weight of the juveniles.
\end{abstract}

Index terms: Amphibians; feed and feeding; frog nutrition; nutritional requirement; protein.

\begin{abstract}
RESUMO
Um dos principais entraves da ranicultura é a falta de conhecimento sobre as exigências nutricionais dos girinos que possibilitem aos nutricionistas a elaboração de uma dieta ideal para esta fase, reduzindo os custos operacionais e promovendo a homogeneidade do lote. Portanto, este estudo teve por objetivo estudar a anatomia do tubo digestivo e a morfometria dos intestinos, médio e posterior, dos girinos de rã-touro Lithobates catesbeianus, visando fornecer subsídios aos nutricionistas para os ajustes no balanceamento de rações adequadas para esta espécie. A população de girinos que receberam o regime alimentar denominado RA3, que consistiu em um aumento quinzenal crescente, durante 60 dias, dos níveis de proteína na ração (de 32 a 45\% de PB) apresentaram em relação ao ganho de peso, taxa de sobrevivência e homogeneidade na passagem dos estágios larvais, os melhores resultados quando comparados aos demais regimes alimentares avaliados. Adicionalmente, a morfometria dos intestinos dos animais submetidos ao RA3 apresentou maior comprimento $(419,2 \mathrm{~mm})$ e o maior calibre na porção do intestino médio onde ocorre a maior absorção dos nutrientes, podendo-se inferir que este fato está relacionado com a altura das pregas intestinais absortivas resultado do fornecimento de uma dieta com melhor qualidade confirmado pelo peso dos imagos.
\end{abstract}

Termos para indexação: Anfíbios; alimento e alimentação; nutrição de rã; exigência nutricional; proteína.

\section{INTRODUCTION}

Given the significant diversity of the existing frog species and the many aspects involving them, numerous differences of structural, anatomical, and histological nature are observed in their digestive system.

Based on the increase in the commercial farming of some species of these amphibians, especially the bullfrog (Lithobates catesbeianus), formerly known as Rana catesbeiana, Shaw 1082 (Frost et al., 2006), several studies have been proposed seeking to determine their nutritional requirements.

Raising tadpoles - the strictly aquatic period of frog farming - is the basis for obtaining good results from the activity, in which great losses, and/or low animal performance are recorded, usually with likely signs of malnutrition. Albinati and Lima (1994a) commented that the main problem in raising Lithobates catesbeianus is related to the composition of a proper nutritional diet, 
especially concerning the protein index, given the lack of knowledge of its nutritional requirements.

Relationships between dietary regimen and the characteristics of the digestive tract have been studied in other animal groups, for which technology has already reached more-advanced stages, which has led to the development of a suitable diet for the requirements necessary for better nutritional performance.

However, frog nutrition, especially in their first stage of life, is far from having established requirement standards that could be used by nutritionists, and this hinders the expansion of frog farming. Therefore, to develop a diet better suited to the nutritional requirements of tadpoles, further studies should be carried out on the morpho-physiology of their digestive tract as well as their anatomical characteristics, correlating them with their habitat and feeding habits.

In this scenario, the present study aimed to evaluate the anatomy of the digestive tract and the morphometry of the midgut and hindgut of bullfrog tadpoles (Lithobates catesbeianus), as well as the productive performance of these animals so as to provide subsidies for nutritionists to make the necessary adjustments in production and balancing of proper diets for this species.

\section{Lifecycle and reproduction of the frogs}

The lifecycle of frogs, as in most amphibian species, starts in the water; these animals keep a close relationship with the aquatic medium for a good part of their life. To reproduce, they prefer small ponds or waterways, where they will spawn the tadpole eggs. To reproduce, frogs must reach sexual maturity and be in an environment with the proper conditions.

After fecundation, the bullfrog egg starts its development from embryo to larva, which has a tail, heartbeats, and external gills (beginning). It gradually starts to grow and change; the gills start to function inside the body, with the lateral siphon remaining for the flow of water, which comes in through the mouth and passes by the gills, allowing respiration. Over time, the larva changes its body form, becoming what is known as tadpole. The tadpole then undergoes a continuous physiological process called metamorphosis, which consists of the alteration in the morphology and physiology of the frog that enable its survival in the terrestrial environment, turning into a juvenile and later an adult (Altig, 2007).

The life of a tadpole can be divided into three stages: initial, growth, and metamorphosis. Many studies have been conducted in an attempt to characterize the development of tadpoles (Gosner, 1960; Lima;
Agostinho, 1992). The classification proposed by Gosner (1960) is the most widely used, because it shows that the tadpole development is complex and distributed into 46 stages. From stage 1 to 25 , the alterations described correspond to the embryonic changes. Thus, the growth itself takes place between stages 26 and 40, and, later, metamorphosis is characterized in the final growth stages, from 41 to 46.

In the embryonic life stage, which corresponds to stages 1 to 25 (Gosner, 1960), the nutritional requirements responsible for the animal development are obtained through the consumption of the yolk reserve. However, as soon as the yolk sac is absorbed and the labial denticles are developed, the tadpole starts to consume organisms from the plankton and periphyton, in addition to bacteria, protozoa, and organic debris floating on the water. Altig (2007) stated that frog larvae utilize a wide variety of foods in their natural environments, feeding on particles suspended on the water. However, they control their feeding and evacuation rates in response to the quality of the food.

According to the observations of Sipaúba-Tavares, Morais and Stéfani (2008) on tadpoles fed diets containing algae, plankton, and a commercial feed, when different planktonic organisms were offered, the preference in the first 14 days was for zooplankton of the order Cladocera, $50.6 \%$ of the ingested zooplankton and, next, for phytoplankton of the group Chlorophyta, representing $88.72 \%$ of the phytoplankton ingested, demonstrating an alteration in their feeding behavior.

As tadpoles grow, changes are observed in their feeding habits, as they start to also consume plant and animal residues and even their own stools (Reeder, 1964; Steinwascher, 1978). The tadpole feeds constantly during this stage, increasing its weight rapidly until it reaches the metamorphosis climax, when stops feeding, thus losing weight and turning into a juvenile.

Metamorphosis is a rather stressful stage for frogs, and the anatomic-physiological changes that take place during this period are complex and problematic (Cosgrove, 1984). In this stage, animals cease eating and start to make use of the organic reserves from the fat tissue and from the tail. The protein derived from the embryonic structure, e.g., tail and gills, is degraded by the action of cathepsins, in the lysosomes, which display a sharp increase in activity during this metamorphosis phase, according to Altig (2007). Additionally, they suffer a marked reduction in the relative length of their digestive tract, indicating the change of feeding habit from herbivore to carnivore (Albinati; Lima, 1994b). 


\section{Dietary regimen}

Seixas Filho et al. (2006) stated that the performance of bullfrogs is basically related to feeding and alterations in the liver function. In this regard, the authors observed, from the analysis of the liver of bullfrogs fed with commercial diets, vacuolization and rupture of the cell contour, in addition to rarefaction and hydropic cell degeneration associated with protein deficiency. Additionally, this study indicated that when the gastrointestinal tract of bullfrog tadpoles was evaluated only on the 25th day after exogenous feeding, liver cells with a more compact glandular arrangement appeared, suggesting functionality; it can be thus inferred that the administration of a diet with a high level of nitrogen from the beginning of raising may be associated with a case of toxicity in the animal for a lack of physiological condition to its metabolization, resulting in mortality, reduced growth, and heterogeneity of the population.

The nutritional ecology and digestive physiology of tadpoles remain, for the most part, enigmatic and uninvestigated. Most studies to date have focused on oral morphology, observations of feeding behavior, and gut content analyses of common species of anuran larvae. Dietary protein seems to be a pivotal nutrient that results in better tadpole growth and development (Pryor, 2014).

\section{Anatomy and morphometry of the digestive tract of tadpoles}

Seixas Filho et al. (2000) emphasized the importance of knowing the morphology of the digestive tract of fish due to the wide variety observed in the many species, relating them to dietary regimens and lifestyles. Altig (2007) reported that the length of the digestive tract is important for the analysis of the quantitative aspects of digestion and food adsorption, remarking that there is a confuse diversity of terms utilized to measure or describe the morphology of tadpoles.

The intestinal passage where digestions enzymatic and bacterial take place is located immediately after the foregut, that begins at the short esophagus and extend into of the manicotto (Ueck, 1967), extending from the midgut, that begins immediately posterior to the manicotto and ends at the posterior opening of the hepatopancreatic duct (Viertrel; Richter, 1999) in this segment, the duodenum begins at the orifice of the hepatopancreatic duct and extends dorsally to form a loop that descends on the right and rises on the left. The boundary between the duodenum and the ileum is indistinct. The ileum extends ventrally in a left-handed outer spiral and then from posterior to anterior in 4-8 conter-clockwise coils (Ueck, 1967) to the hindgut, where the colon comprise the last two loops of the intestinal spiral and can be distinguished from the ileum by its greater diameter and the rectum is positioned longitudinally and dorsally in relationship the abdominal cavity and together with bladder and ureters lead into the cloaca (Reeder,1964; Viertrel; Richter, 1999). The ileum reabsorbs metabolites digested by the pancreatic enzymes, and its cells probably secrete various enzymes and intense enzymatic activity along with the presence of symbiotic microorganisms in the colon (Ueck, 1967).

Anuran larvae lack a pylorus, so the midgut begins immediately posterior to the manicotto and ends at the posterior opening of the hepatopancreatic duct. Two spirals are formed, and a fibrous or muscular infolding of the intestinal wall (Ueck, 1967) enlarges the anterior secretory and posterior resorptive surface of the intestine, controls clearance time of food through the gut, causes a narrowing of the intestine passage, and slows mixing of the pancreatic enzymes with the food mass.

The lack of secretory digestive granules in the duodenal cells suggests that this part the intestine does not produce its own digestive enzymes but resorbs substances metabolized by pancreatic enzymes (Fox; Mahoney; Bailey, 1970). The Ileum resorbs metabolites digested by pancreatic enzymes, and the microvillous cells probably secrete various enzymes (Ueck, 1967). In the colon intense enzyme activity and the presence of microorganisms in a characteristic layer near the epithelial cells suggest the symbiotic breakdown of plant cell walls (Viertrel; Richter, 1999). The cuboidal, microvillous and ciliary cells of the rectum indicate resorptive and transport functions, especially water (Fox et al., 1972). Research has been carried out reporting that the larval development stage also expresses the shape, the direction, the folding pattern, and the position of structures of the larval body, including organs, intestinal convolutions, among others, according to the changes of the larval stages, reaching the climax of metamorphose when apoptosis occurs and tissue reconstruction of the digestive system (Pretty; Naitoh; Wassersug, 1995; Seixas Filho et al., 2013).

Herter (1941) mentioned ratios between intestinal length and fork length of 1.9-to-1 in Rana esculenta and 1.02-to-1 in Rana temporária.

The ileum reabsorbs metabolites digested by the pancreatic enzymes, and its cells probably secrete various enzymes and intense enzymatic activity along with the presence of symbiotic microorganisms in the colon (Ueck, 1967). 


\section{Bértin's coefficient}

To express mathematically the relationships between intestinal length and the feeding habits of fish, Bértin (1958) established a coefficient, called intestinal coefficient (intestinal length/ body length), which varies according to the feeding habits. Several authors (Rodrigues; Menin, 2006; Barbieri; Peret; Verani, 1994; Seixas Filho et al., 2000, 2006, among others) observed intestinal coefficients consistent with the ranges found by Bértin (1958), who considered the intestinal coefficient to vary from 0.2 to 2.5 in carnivores; 0.6 to 8.0 in omnivores; and 0.8 to 15.0 in herbivores.

\section{MATERIAL AND METHODS}

The experiment was conducted in the Laboratory of Biology Research at the Augusto Motta University Center (Centro Universitário Augusto Motta, UNISUAM), located in Rio de Janeiro - RJ, Brazil. A total of 525 Lithobates catesbeianus tadpoles in stage 25 of the Gosner (1960) classification, originating from a breeder selected in the flock of breeders from the same laboratory, were used in this experiment. Tadpoles were transferred to plastic tanks and studied for 60 days. They were distributed into 15 rectangular water-filled tanks with 50-L capacity each, placed side by side on a countertop. The water chlorine, originating from the public distribution supply, was neutralized by the addition of sodium thiosulfate in two 200-L containers connected to each other by PVC tubes, where electric heaters, connected to thermostats, increased and maintained the water temperature at $26{ }^{\circ} \mathrm{C}$. This water was moved by gravity, through PVC tubes of half-inch diameter connected to crystal hoses with 3/16 inch diameter, connectors, and plastic valves (also with an internal diameter of $3 / 16$ inches), into one of the 15 tanks. The valves control the flow of water renewal in the tanks containing the animals. The water was drained by a plastic screen to prevent the tadpoles from escaping. Permanent aeration of the water in the tanks was achieved by using an electric air blower connected to weld PVC pipes linked to crystal hoses, plastic valves with $3 / 16$ inch diameters and a porous stone deposited at the bottom of each tank. PVC pipes with $40 \mathrm{~mm}$ diameter each were cut into two parts (like gutters) with $50 \mathrm{~cm}$ in length, which served as troughs for the feed supply. To determine the temperature, an alcohol thermometer with a scale from 0 to $60^{\circ} \mathrm{C}$ was utilized. Ammonia and $\mathrm{pH}$ levels were measured using commercial kits for fish aquaria. To measure the anatomic pieces, a digital caliper with precision of hundredths of a millimeter was used. An analytical scale with $0.001 \mathrm{~g}$ precision was used for weighing the animals, feeds, and the sodium thiosulfate. Surgical instruments were employed for handling the anatomical parts.

\section{Management of the experimental unit}

Thirty-five tadpoles were placed in each tank at the ratio of one animal per liter of water. The water, with $200 \%$ of its volume per tank renewed every $24 \mathrm{~h}$, was kept at the temperature of $26^{\circ} \mathrm{C}$.

In the morning, samples of each tank were collected to determine $\mathrm{pH}$ and ammonia; feed orts and feces were removed by siphoning the bottom of the tank. After reestablishing the water column, animals received a new feed.

Commercial diets for freshwater fish from the same manufacturer and formulated to meet the different fish-size ranges from larva to the final stages were used, containing $22 \%, 28 \%, 32 \%, 36 \%, 40 \%, 45 \%$, and $55 \%$ crude protein in their formulae, respectively (Table 1). These diets were employed in the preparation of five dietary regimens with increasing protein levels (Table 2).

After liquefaction, forming $0.5 \mathrm{~mm}$ granules, diets were then moistened and compressed manually into balls to maintain a longer period of stability in the water, aiming to improve the quality of the liquid medium and to maximize its intake by the tadpoles. These granules were deposited at the bottom, in the PVC troughs. Five grams of feed were supplied initially per tank, increasing according to the variation in the weight of the animals observed in every biometric measurement (determination of weight and size) during the experimental period.

\section{Collection, biometric measurements, fixation, and maintenance of animals}

Every 15 days, all animals were subjected to biometric measurements using digital calipers accurate to $0.01 \mathrm{~mm}$. Tadpoles were measured from the snout up to the insertion of the tail (fork length), on a moistened towel tissue in an attempt to hold the animals without dehydrating them. Soon after, they were returned to their original tanks, except for nine animals that were collected at random per treatment for the morphometric analysis on days $0,15,30,45$, and 60 of the experimental period. After stunning, having their metabolism reduced by immersion in an ice bath at $4{ }^{\circ} \mathrm{C}$ and anesthetized with $1 \%$ menthol added to water, they were sacrificed by a transverse section of the spine immediately after the 
occipital region to preserve the organs, and then they were fixed in 10\% formaldehyde (Seixas Filho et al., 2013). For a better tissue fixation, a ventral longitudinal incision of the intermediate region was made from the oral orifice up to the posterior limit of the abdomen and the fixative was injected orally using a hypodermal syringe. The specimen remained in this solution for $24 \mathrm{~h}$ and was then transferred to a $70 \%$ alcohol solution where it remained until the morphometric analysis.

\section{Morphometric analysis}

Three tadpoles were collected from each tank on the 45 th day of the experiment and used for the measurements, totaling 45 animals.

The anatomical description of the layout of the intestines in the peritoneal cavity was achieved by amplifying laterally the longitudinal section made for fixing the specimen. The midgut and hindgut were dissected and described according to the anatomical planes of demarcation (cranial, caudal, ventral, dorsal and lateral right and left).

The intestines were measured after the manicotto (Viertel; Richter, 1999) up to the final portion of the rectum. The diameter of the intestines was measured considering their width in three different positions, i.e., anterior, middle, and posterior positions.

\section{Studies of absorption area}

To check the potential of absorption of each segment of the tadpoles' intestine, because of its anatomical shape, it was considered as a cylinder. From this observation, the formula of the cylinder area was used (Figure 1) for the application of the calculations (Borba, 2007).

Table 1: Commercial diets containing 22\%, 28\%, 32\%, 36\%, 40\%, 45\%, and 55\% crude protein (CP) used in the feeding of bullfrog tadpoles.

\begin{tabular}{crrrrrrr}
\hline Guaranteed level & \multicolumn{7}{c}{ Diet (\% CP) } \\
\cline { 2 - 7 } & \multicolumn{1}{c}{22} & \multicolumn{1}{c}{28} & \multicolumn{1}{c}{32} & \multicolumn{1}{c}{ (36 } & \multicolumn{1}{c}{40} & \multicolumn{1}{c}{45} & \multicolumn{1}{c}{5} \\
\hline Maximum moisture & 13.0 & 13.0 & 13.0 & 13.0 & 13.0 & 13.0 & 13.0 \\
Crude protein (CP) & 22.0 & 28.0 & 32.0 & 36.0 & 40.0 & 45.0 & 55.0 \\
Ether extract (minimum) & 4.0 & 4.0 & 7.0 & 8.0 & 8.0 & 10.0 & 7.0 \\
Fibrous matter (maximum) & 10.0 & 10.0 & 7.0 & 7.0 & 7.0 & 5.0 & 7.0 \\
Ash (maximum) & 14.0 & 14.0 & 2.6 & 3.1 & 3.1 & 3.0 & 2.6 \\
Calcium - Ca (maximum) & 3.0 & 3.0 & 12.0 & 14.0 & 14.0 & 14.0 & 12.0 \\
Phosphorus - P (minimum) & 1.0 & 0.6 & 2.0 & 2.5 & 2.5 & 2.0 & 2.0 \\
\hline
\end{tabular}

Basic composition: Soybean meal, fish meal, wheat bran, corn gluten meal $60 \%$, meat and bone meal, corn, blood meal, fish oil, calcium carbonate, dicalcium phosphate, vitamin ${ }^{1}$ and mineral ${ }^{2}$ salt supplement, antioxidant ${ }^{3}$.

${ }^{1}$ Composition per kg: vit. A - 12,000 IU; vit. D3 - 4,000 IU; vit. E - 150 IU; vit. K - 10 IU; folic acid - 10 mg; biotin - 0.8 mg; choline 500 mg; niacin - 150 mg; calcium pantothenate - 50 mg; thiamine - 30 mg; riboflavin - 30 mg; pyridoxine B6 - 30 mg; vit. B12 - 35 $\mu \mathrm{g}$; vit. C - $300 \mathrm{mg}$.

${ }^{2}$ Composition per kg: Mg - 700 mg; Mn - 30 mg ; Zn - 200 mg ; Cu - 15 mg ; Fe - 100 mg ; I - 1 mg; Se - 0.3 mg

${ }^{3}$ Ethoxyquin - $250 \mathrm{mg}$.

Table 2: Crude protein levels (\%) of the commercial diets administered in the different dietary regimens to bullfrog tadpoles for 60 days.

\begin{tabular}{cccccc}
\hline Period & \multicolumn{5}{c}{ Dietary regimen $($ DR) $(\%$ crude protein in the diet) } \\
\hline Days & DR1 & DR2 & DR3 & DR4 & DR5 \\
$0-15$ & 22 & 28 & 32 & 36 & 40 \\
$15-30$ & 28 & 32 & 36 & 40 & 45 \\
$30-45$ & 32 & 36 & 40 & 45 & 45 \\
$45-60$ & 36 & 40 & 45 & 55 & 55 \\
\hline
\end{tabular}




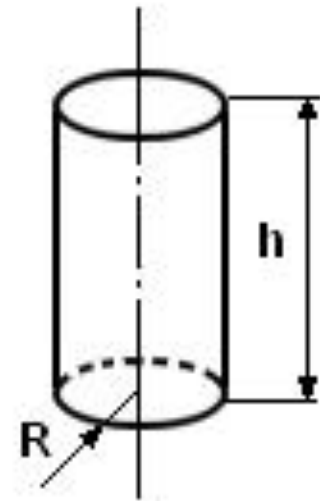

Figure 1: Detail of the cylinder figure, corresponding to the shape of the intestinal loops that were measured. The calculation of the absorption areas for each segment was based on the cylinder area.

The set of intestine areas, except for the height of the deformations of the intestinal wall, were considered as areas of absorption of the midgut, duodenum and ileum, colon and rectum. The radius $(\mathrm{R})$ was calculated as the average of the measurements of the portions (anterior, middle, and posterior) of the intestinal segment, generating the average diameter.

To obtain the coefficient of absorption of each intestinal segment, its percentage was calculated in relation to the total intestine area, which was given by: $S=2 \pi R(R+h)$, where $\mathrm{S}$ - total sum of bases and lateral area of the cylinder; $\mathrm{S}_{\mathrm{L}}$ - lateral area of the cylinder; $\mathrm{R}$ - radius; $\mathrm{h}$ - cylinder height.

\section{Statistic analyses}

For the analysis of the dietary regimen data, intake was calculated as the difference between the amounts of feed supplied and the orts. Apparent feed version was obtained as the ratio between feed intake and weight gain. The weight gain in each period, in turn, was obtained as the difference between the weights calculated from the two consecutive biometric measurements. A completely randomized block design in a split-plot arrangement with three replicates was adopted. The dietary regimens (DR) were tested in the plots, and the subplots comprised five biometric measurements: one at the implementation of the experiment ( 0 days) and others at 15, 30, 45, and 60 days after the implementation. The data were subjected to analysis of variance and the F test. Dietary regimens were compared by the Newman-Keuls test at $5 \%$ probability level.

Data originating from morphometric measurements, obtained from the animals at 45 days of age, were subjected to analysis of variance, and the effect of the regimens was tested by the Student-Newman-Keuls test at 5\% probability level.

\section{RESULTS AND DISCUSSION}

\section{Dietary regimen}

The tadpoles subjected to the dietary regimen DR5 showed the highest average weight at 60 days (Table 3 ). However, they had the lowest weight gain between the 45th and 60th days (Table 4), in addition to higher mortality (Table 5). This indicates that this regimen was not suitable for this growth phase of the tadpoles, according to the findings of Seixas Filho et al. (2006).

The other regimes did not show significant differences between each other $(\mathrm{P}>0.05)$ as to length and weight gain at 60 days, indicating that, as regards these parameters, any of these could be indicated for the management of animals. Regimen DR1, which showed the lowest crude protein values, presented the worst feed conversion compared with the others, in the first 15 days of experimentation, which may lead to the non-recommendation of this regimen. Thus, regimes DR2, DR3 and DR4 appear to be the most appropriate for this type of management.

\section{Anatomical description}

In this study, the anatomical investigation of the intestines originally followed by divisions mentioned by Viertel and Richter (1999). The peritoneal cavity is wide, and the digestive tract occupies its entire extension (Figure $2 \mathrm{~A}, \mathrm{~B}, \mathrm{C}$ and D). It was noted that the shape, the direction and the pattern of intestinal folding vary according to the size of the peritoneal cavity. The organs showed to be directly related to the shape of the peritoneal cavity, and this cavity was related to the body shape, as described by Seixas Filho et al. (2000) for fish.

At the end of the manicotto in the stage 37 of Gosner (1960), the hepatopancreatic duct is bound to the intestinal canal, indicating the beginning of the midgut (the anterior part of the embryonic canal). The midgut is short and has a large caliber. It starts in the last third of the peritoneal cavity, moving in the left lateral caudal direction and over the middle portion of the rectum, binding its ventral face to the left lateral wall of the cavity. It then takes a dorsal cranial direction, forming a double spiral with the colon, ileum, and duodenum. In the middle portion of the peritoneal cavity, the hepatopancreatic duct ends at the intestine, determining the region of transition between the midgut and the duodenum. 

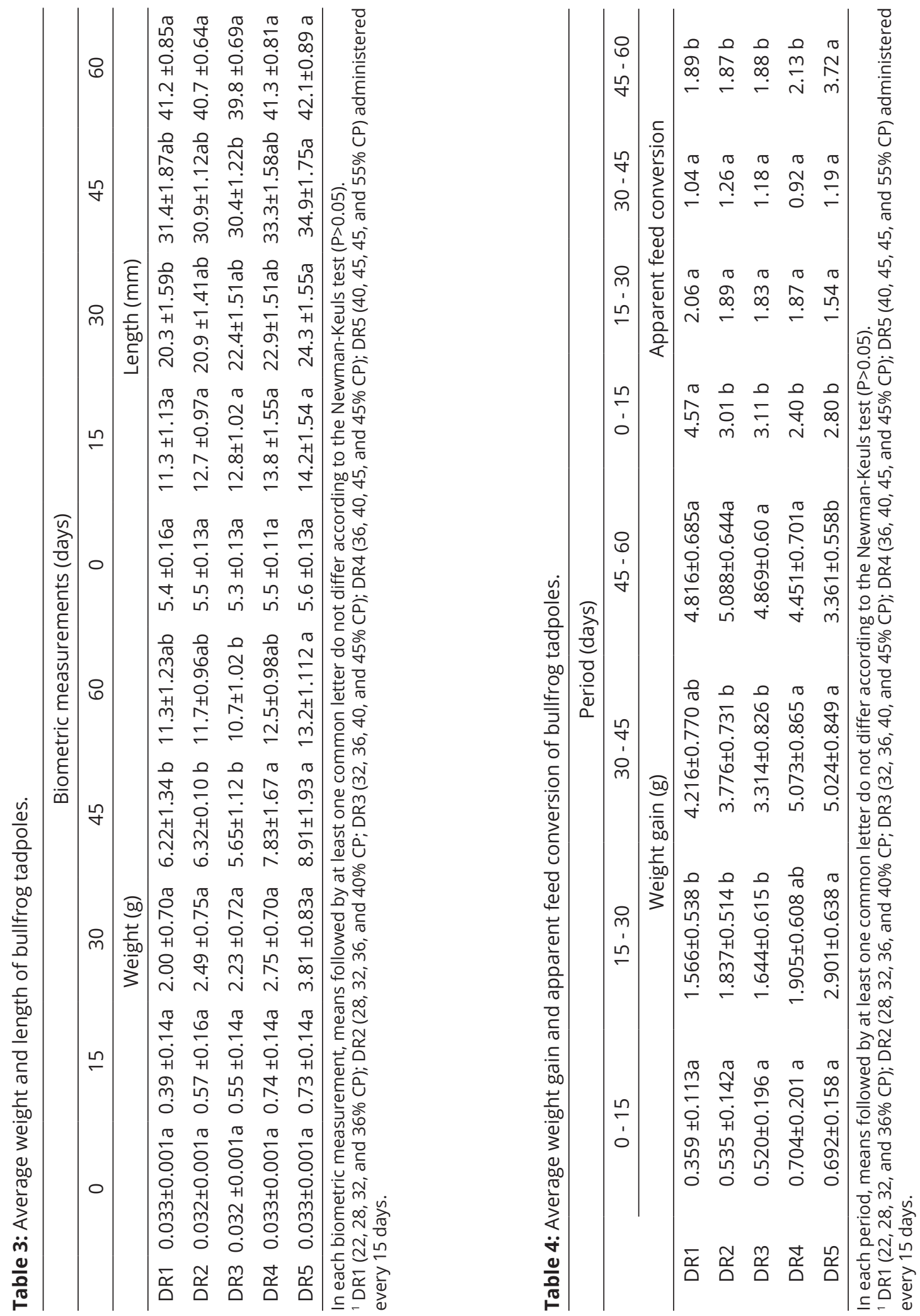
Table 5: Survival of bullfrog tadpoles fed commercial diets with different crude protein (CP) contents, for 60 days.

\begin{tabular}{cccccc}
\hline \multicolumn{7}{c}{ Survival (\%) } \\
\hline & 0 & 15 & 30 & 45 & 60 \\
\hline DR1 & 100 & 100 & 90.48 & 90.48 & 86.67 \\
DR2 & 100 & 100 & 86.67 & 84.76 & 80.95 \\
DR3 & 100 & 100 & 93.33 & 90.48 & 86.67 \\
DR4 & 100 & 100 & 86.67 & 86.67 & 83.81 \\
DR5 & 100 & 87.62 & 73.33 & 71.43 & 65.71 \\
\hline
\end{tabular}

1 DR1 $(22,28,32$, and 36\% CP); DR2 (28, 32, 36, and 40\% CP; DR3 $(32,36,40$, and 45\% CP); DR4 (36, 40, 45, and 45\% CP); DR5 $(40,45,45$, and 55\% CP) administered every 15 days.

The first segment of the duodenum is short, with a double folding of the canal - first to the left, and then right in the cranial direction, still in the midline of the peritoneal cavity. The limit between the duodenum and the ileum is indistinct, as stated by Viertel and Richter (1999).

The ileum is extended vertically counterclockwise. This trajectory is interrupted when it binds to the left lateral wall of the abdominal cavity, when it folds on itself like a short spring whose curves are strongly bound by an aponeurosis bundle originating from the dorsal peritoneal wall, which supports each spiral loop in the abdominal cavity.

The limit between the ileum and the colon is marked by the abrupt increase in the caliber of the intestinal canal. Ueck (1967) mentioned that the colon length comprises the last two spiral loops of the intestine of Xenopus laevis tadpoles. However, in an investigation with Lithobates catesbeianus, the colon length was found to encompass the four last loops until it was bound medially to the back of the peritoneal cavity wall, where the rectum begins.

The rectum is placed longitudinally and dorsally to the peritoneal cavity wall, beginning at the region of the last third of this cavity and extending up to the cloaca.

\section{Intestinal morphometry}

The results of the measurements obtained in the morphometric evaluations of the intestines of the tadpoles are given in Table 6, which shows the mean values of the nine samples collected in each one of the five dietary regimes.
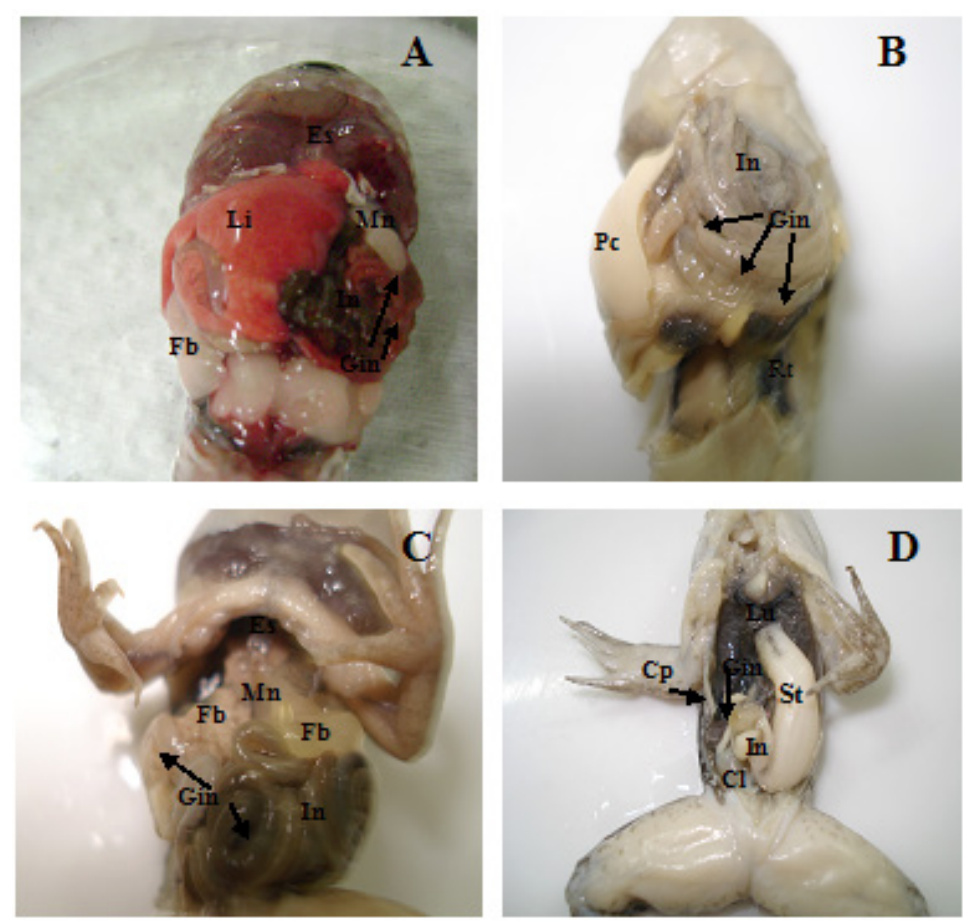

Figure 2: Shape and deposition of organs in the peritoneal cavity and direction and pattern of intestinal folding in tadpoles of bullfrog at Gosner (1960)'s stages $37(A)$ and $(B)^{*}, 42(C)^{*}$ compared with the juvenile and (D)*.

$\mathrm{Li}=$ liver; $\mathrm{In}=$ intestine; $\mathrm{Es}=$ esophagus; $\mathrm{Mn}=$ Manicotto; $\mathrm{Fb}=$ fat body; $\mathrm{Gin}=$ gyrus intestinal $(\rightarrow) ; \mathrm{Pc}=$ peritoneal cavity; St = stomach; Lu = lung; $\mathrm{Cl}=$ cloaca ( ${ }^{\star}$ to better view the organs, the liver was removed). 


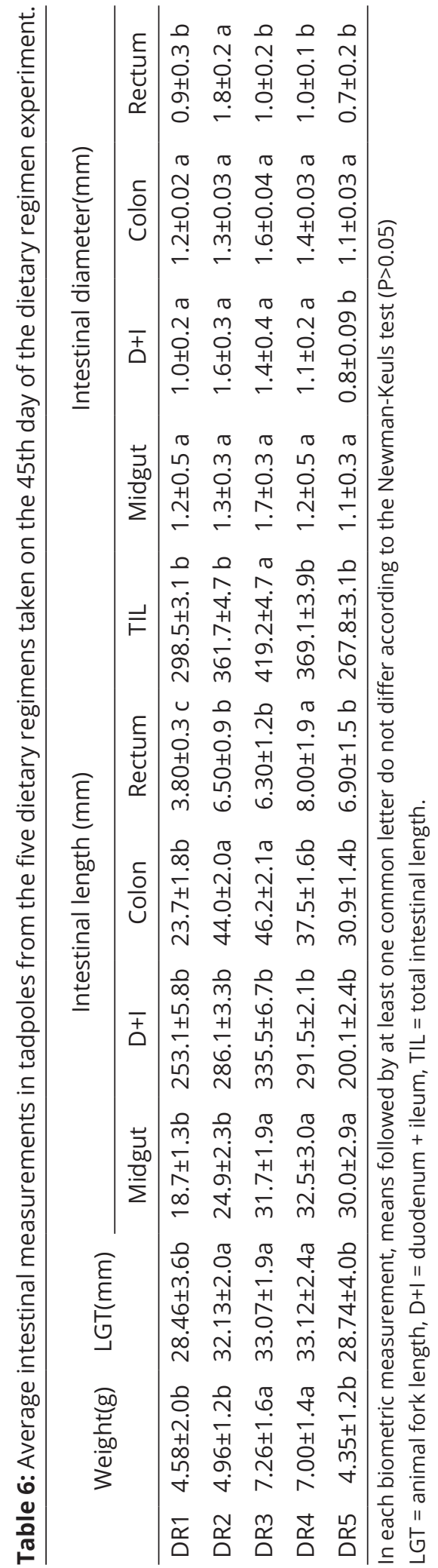

The midgut of the animals in dietary regimen 3 showed the largest average caliber, with $1.7 \mathrm{~mm}$ (Table 6), with no statistically relevant variation in caliber between the groups. On the other hand, the group DR5 the caliber of the duodenum + ileum was minor with compared with others group $(\mathrm{P}<0,05)$. Besides having animals with the longest intestine in total extension $(\mathrm{P}<0,05)$, DR3 also showed greater development of the absorptive intestinal areas (duodenum + ileum).

As regards the intestinal segment corresponding to the duodenum + ileum, DR2 showed a larger caliber, with its anterior portion, where a greater catalase activity originating from the anterior intestine is expected, having a larger caliber.

The colon diameter showed to be equivalent for all treatments. However, its anterior portion showed to have a larger caliber in DR3. In the other portions, no expressive differences were found among the treatments.

The rectum did not show significant variations in the caliber of the portions, except for the posterior segment of the animals from DR2, which appeared to have a higher caliber.

The metabolite absorption areas and the areas of enzymatic activity are present in over eighty percent of the total intestinal length (Table 8). The rectum, where basically water absorption takes place, does not represent more than two percent of the total intestinal length.

In each column, means followed by a least one common letter do not differ according to the StudentNewman-Keuls test $(\mathrm{P}>0.05)$.

For the animal weight, DR2, DR3 and DR4 achieved the best yields, respectively (Table 7). Regarding the fork length, there were no significant statistical differences. For the larval development stages, tadpoles on DR2, DR3, and DR4 displayed greater population homogeneity, whereas DR1 and DR5 showed extreme heterogeneity.

The duodenum + ileum segment clearly stood out regarding the potential of absorptive area (Table 8) as compared with the total intestinal area, ranging from $69.95 \%$, for the animals on DR5, to $83.15 \%$ for those on treatment DR1. Next is the colon, which ranged from $9.17 \%$, for DR1, to $14.50 \%$, for DR5. The midgut ranged varied from $6.62 \%$, for DR 1 , to $13.52 \%$, for DR5. The rectum contributed with the lowest fractions, ranging from $1.07 \%$, in DR1, to 2.02, in DR5. 
Table 7: Average weight and length of tadpoles on the 45th day of the experiment and the stages of development into the sample of nine animals from each group.

\begin{tabular}{cccc}
\hline Dietary regimen & Stages & Weight $(\mathrm{g})$ & Length $(\mathrm{mm})$ \\
\hline DR1 & $31,32,34,35,36,39,42$ & $4.59 \mathrm{~b}$ & $28.46 \mathrm{a}$ \\
DR2 & $36,37,39,40,41$ & $4.96 \mathrm{~b}$ & $32.13 \mathrm{a}$ \\
DR3 & $35,36,37,38,41$ & $7.26 \mathrm{a}$ & $33.07 \mathrm{a}$ \\
DR4 & $35,37,38,40,41$ & $7.06 \mathrm{a}$ & $33.12 \mathrm{a}$ \\
DR5 & $29,36,37,38,41,42$ & $4.35 \mathrm{~b}$ & $28.74 \mathrm{a}$ \\
\hline
\end{tabular}

Table 8: Percentage of the area of the midgut, duodenum + ileum, colon, and rectum of bullfrog tadpoles, at 45 days, subjected to different dietary regimens.

\begin{tabular}{ccccc}
\hline Dietary regimen & \multicolumn{4}{c}{ Intestinal area (\%) } \\
\hline DR1 & Midgut & Duodenum + lleum & Colon & Rectum \\
\hline DR2 & $6.62 \mathrm{~b}$ & $83.15 \mathrm{a}$ & $9.17 \mathrm{~b}$ & $1.07 \mathrm{~b}$ \\
DR3 & $7.25 \mathrm{~b}$ & $78.12 \mathrm{~b}$ & $12.99 \mathrm{a}$ & $1.63 \mathrm{ab}$ \\
DR4 & $8.45 \mathrm{~b}$ & $78.56 \mathrm{ab}$ & $11.84 \mathrm{ab}$ & $1.15 \mathrm{~b}$ \\
DR5 & $9.17 \mathrm{~b}$ & $75.37 \mathrm{~b}$ & $13.55 \mathrm{a}$ & $1.90 \mathrm{a}$ \\
\hline
\end{tabular}

In each column, means followed by a least one common letter do not differ according to the Student-Newman-Keuls test $(P>0.05)$.

\section{Analysis of the intestinal coefficient}

By applying Bértin (1958)'s calculation, utilized to define the feeding habit of fish, to the analyzed tadpoles, an intestinal coefficient of 11.00 was found. It can thus be inferred that Lithobates catesbeianus tadpoles could be considered to have an herbivorous feeding habit.

\section{CONCLUSIONS}

Based on the results, it can be inferred that dietary regimen DR3 achieved the best results among of treatments tested. It provided the best weight gain, animals with longest intestine in total extension, greater development of the absorptive intestinal areas and areas of enzymatic activity, higher average caliber, and an anterior portion, where a greater catalase activity originating from the anterior intestine is expected, with a higher caliber in relation to the total potentially absorptive area of the intestines. It can also be inferred that the metaboliteabsorption areas and areas of enzymatic activity occur in more than $80 \%$ of the total intestinal length. The tadpoles from treatments DR2, DR3, and DR4 showed greater population homogeneity, whereas DR1 and DR5 demonstrated extreme heterogeneity. However,
DR4 and DR3 had the highest share of the population at more advanced stages. Based on Bértin (1958)'s intestinal coefficient, it can be inferred that the Lithobates catesbeianus tadpoles studied here have an herbivorous feeding habit. Nevertheless, the reviewed literature diverges from this result, indicating the tadpole to be omnivorous. Therefore, further investigations should be proposed to elucidate these results.

\section{REFERENCES}

ALBINATI, R. C. B.; LIMA, S. L. Biometria do tubo digestivo do girino da rã-touro, Rana catesbeiana, em diferentes estágios de desenvolvimento. Arquivos da Escola de Medicina Veterinária - UFBA, 1(18):26-32, 1994a.

ALBINATI, R. C. B.; LIMA, S. L. Tempo de trânsito do alimento pelo trato gastrointestinal de girino rã-touro (Rana catesbeiana). Arquivos da Escola Medicina de Veterinária - UFBA, 1(18):61-69, $1994 b$.

ALTIG, R. A primer for the morphology of an anuran tadpoles. Herpetological Conservation and Biology. 2(1):71-74, 2007.

BARBIERI, G.; PERET, A. C.; VERANI, J. R. Notas sobre a adaptação do trato digestivo ao regime alimentar em espécies de peixes da região de São Carlos (SP). I. Quociente intestinal. Revista Brasileira de Biologia, (54):63-69, 1994. 
BÉRTIN, L. Appareil digestif. In: GRASSÉ, P. P. (Ed.). Traité de Zoologie, Paris: Masson, 1958, v. 13, p.1249-1301.

BORBA, A. J. G. A. Cálculo do cilindro reto. Available in: <http://www.webcalc.com.br/frame.asp?pag=http://www. webcalc.com.br/matematica/cilindro_reto.html>. Access in: November,10, 2007.

COSCROVE, G. E. Tratamento e doenças de anfíbios. In: KIRK, R. W. Atualização terapêutica veterinária - pequenos animais. São Paulo: Monole, 1984, p. 680-682.

FOX, H.; BAILEY, E., MAHONEY, R. Aspects of the ultra-structure of the alimentary canal and respiratory ductus in Xenopus laevis larvae. Journal morphology, (138):387-406, 1972.

FOX, H.; MAHONEY, R.; BAILEY, E. Aspects of the ultra-structure of the alimentary canal and associated glands of the Xenopus laevis larvae. Archives of Biology Liège, (81):2150, 1970.

FROST, D. R. et al. The amphibiam tree of life. Bulletin American Museum of Natural History. (297):1-370, 2006.

GOSNER, K. L. A simplified table for staging anuran embryos and larvae with notes on identification. Herpetologica, (16):183-190, 1960.

HERTER, K. Die physiologie der amphibien. In: Handbuch der Zoologie. KÜKENTHAL, W. (ed.). Gruyter: Berlin.1941. 252 p.

LIMA, S. L.; AGOSTINHO, C. A. A tecnologia de criação de rãs. Viçosa, MG: Universidade Federal de Viçosa, 1992, 168p.

RODRIGUES, S. S.; MENIN, E. Adaptações anatômicas da cavidade bucofaringiana de Pseudoplatystoma corruscans (spix e agassiz, 1829) (siluriformes, pimelodidae) em relação ao seu hábito alimentar. Revista Ceres, 53(305):135-146, 2006.

PRETTY, R., NAITOH, T.; WASSERSUG, R. J. Metamorphic shortening of the alimentary tract in anuran larvae (Rana catesbeiana). The Anatomical Record, (242):417-423, 1995.

PRYOR, G. Tadpole nutritional ecology and digestive physiology: Implications for captive rearing of larval anurans. Zoo Biology, (33):502-507, 2014.

REEDER, W. G. The digestive system. In: NOORE, J. A. (Ed). Physiology of the amphibia. New York: Academic Press, p. 99-150, 1964.
SEIXAS FILHO, J. T. et al. Separata de: Anatomia funcional e morfometria dos intestinos e dos cecos pilóricos do Teleostei (Pisces) de água doce piau (Leporinus friderici, Bloch, 1794). Revista Brasileira de Zootecnia, 6(29):21812192, 2000.

SEIXAS FILHO, J. T. et al. Efeito dos níveis de proteina bruta em rações comerciais no desempenho de girinos de rã-touro (Rana catesbeiana, SHAW, 1802) utilizando o comprimento como parâmetro biológico. Secretaria de Agricultura e Abastecimento do Estado de São Paulo. São Paulo: Instituto Biológico, v. 68, suplemento raib/191/135, 2006. Available in: <http://www.biologico.sp.gov.br/ biologico/v68_supl_raib/191.PDF>. Access in: October, 24, 2007.

SEIXAS FILHO, J. T. et al. Estudo anatômico e morfométrico do intestino de girinos da rã-touro em estágios de clímax metamórfico. SaBios - Revista de Saúde e Biologia, 2 (8)23-30, 2013.

SIPAÚBA-TAVARES, L. H.; MORAIS, J. C. L.; DE STÉFANI, M. V. Comportamento alimentar e qualidade de água em tanques de criação de girinos de rã-touro Lithobates catesbeianus. Acta Scientarium. Animal Science, (30):95101, 2008.

STEINWASCHER, K. The effect of coprophagy on the growth of Rana catesbeiana tadpoles. Copeia, American Society of Ichthyologists and Herpetologists (ASIH). p.130-134, 1978. Available in: <http://www.jstor.org/stable/1443833>. Access in: November, 10, 2015.

UECK, M. Der manicotti glandular ("Drüsenmagen") der Anurenlarve in Bau, Funktion und Beziehung, zur Gesamtlänge des Darmes. Eine mikroskopichanatomische, histochemische, und electronenoptische Studie an der omnivoren und mikrophagen larve von Xenopus laevis und der carnivoren und makrophagen larve von Hymenochirus boettgeri (Anura, Pipidae). Zeitschrift für Wissenschaftliche Zoologie, (176):173270, 1967.

VIERTEL, B.; RICHTER, S. Anatomy: viscera and endocrines. In: MCDIARMID, R. W.; ALTIG, R. Tadpoles: the biology of anuran larvae. Chicago: University of Chicago Press, 1999, $444 \mathrm{p}$. 